\title{
Retraction Note to: Monitoring and early warning of loess landslide based on distributed environment and effectiveness calculation of physical training
}

\section{Erxia Liu ${ }^{1}$}

Published online: 3 November 2021

(c) Saudi Society for Geosciences 2021

Retraction Note to: Arabian Journal of Geosciences (2021) 14: 1597 https://doi.org/10.1007/s12517-021-07890-x

The Editor-in-Chief and the Publisher have retracted this article because the content of this article is nonsensical. The peer review process was not carried out in accordance with the Publisher's peer review policy. The author has not responded to correspondence regarding this retraction.

The original article can be found online at https://doi.org/10.1007/ s12517-021-07890-x.

\section{Erxia Liu}

liuerxia1111@126.com

1 Nanyang Institute of Technology, Nanyang 473000, Henan, China 